\title{
Within-tree carbon concentration variation in three Mexican pine species
}

\author{
Variación de la concentración de carbono en tres especies mexicanas de pino
}

\author{
Diego Hernández-Vera a, Marín Pompa-García a*, José I Yerena-Yamallel b, Eduardo Alanís-Rodríguez b \\ *Corresponding author: a Universidad Juárez del Estado de Durango, Facultad de Ciencias Forestales, \\ Río Papaloapan, Valle del Sur, 34120 Durango, México, mpgarcía@ujed.mx \\ b Universidad Autónoma de Nuevo León, Facultad de Ciencias Forestales, km 145 Carretera Linares-Cd. \\ Victoria, Linares, Nuevo León, México.
}

\begin{abstract}
SUMMARY
Assessing carbon content in forest species is considered essential for programs designed to mitigate global warming. A value of $50 \%$ has been assumed as a generic percentage. However, recent research indicates that there are substantial variations in carbon concentration even within a tree or tissues. The aim of this study was to assess the variations of carbon concentration along the longitudinal profile of Pinus durangensis, P. engelmannii and P. leiophylla in northern Mexico, including its components: root, bark, stem, branches, twigs, leaves and fruits. Using a selective sampling design, dominant and well-shaped trees were selected, whose samples were processed by chemical analyses. Results indicated significant differences in the mean concentration of carbon along the longitudinal profile, with the maximum value always at the base of the tree. Variations at the species level were also recorded. Pinus engelmannii had the lowest percentage with $49.31 \%$, followed by P. leiophylla $(50.18 \%)$ and $P$. durangensis $(50.36 \%)$. In the components of all species, the carbon concentration in the bark was higher than in the rest (52.48\%). A wide range of variation was observed in the carbon coefficients of the components of the species, from $47.39 \%$ in the root of $P$. engelmannii to $53.49 \%$ in the bark of $P$. leiophylla. It is therefore appropriate to consider these variations when making more accurate estimates of carbon stocks in forest ecosystems.
\end{abstract}

Key words: Pinus durangensis, Pinus engelmannii, Pinus leiophylla, components, trees.

\section{RESUMEN}

Evaluar el contenido de carbono se considera esencial para programas diseñados a mitigar el calentamiento global. Se ha asumido un valor de $50 \%$ como porcentaje genérico. Sin embargo, investigaciones recientes indican que existen variaciones substanciales en concentraciones de carbono incluso entre árboles y tejidos. El objetivo de este estudio fue evaluar las variaciones de la concentración de carbono a lo largo del perfil longitudinal de Pinus durangensis, P. engelmannii, y P. leiophylla en el norte de México, incluyendo sus componentes: raíz, corteza, tallo, ramas, ramillas, hojas y frutos. Los resultados indican diferencias significativas en la concentración media de carbono a lo largo del perfil longitudinal, con máximos valores siempre en la base del árbol. También se registraron variaciones al nivel de especie. Pinus engelmannii tuvo el más bajo porcentaje con 49,31\%, seguido por P. leiophylla (50,18 \%) y P. durangensis $(50,36 \%)$. En los componentes de todas las especies, la concentración de carbono en la corteza fue más alta que en el resto $(52,48 \%)$. Un amplio rango de variación se observó en los coeficientes de carbono de los componentes de las especies, desde $47,39 \%$ en la raíz de $P$. engelmannii a 53,49 \% en la corteza de $P$. leiophylla. Es por tanto apropiado considerar estas variaciones cuando se hagan estimaciones más precisas de almacenes de carbono en los ecosistemas forestales.

Palabras clave: Pinus durangensis, Pinus engelmannii, Pinus leiophylla, componentes, árboles.

\section{INTRODUCTION}

Global averages of carbon dioxide $\left(\mathrm{CO}_{2}\right)$, methane $\left(\mathrm{CH}_{4}\right)$ and nitrous oxide $\left(\mathrm{N}_{2} \mathrm{O}\right)$ reached their maximum levels in 2014. In 2015 the National Oceanic and Atmospheric Administration (NOAA) found an unprecedented increase $(+3.01$ parts per million $)$ in $\mathrm{CO}_{2}$. Climate change is mainly attributed to greenhouse gasses $(\mathrm{GHG})$. In the period 1990-2014, the annual GHG index increased by $36 \%$, of which $80 \%$ was $\mathrm{CO}_{2}$ (OMM 2016).
Forests are terrestrial ecosystems that capture and store most carbon (Martin and Thomas 2011) and play an important role in the carbon cycle (Wang et al. 2015). Carbon capture and storage give to forests additional value since they contribute to the absorption of GHGs (Aguirre-Calderón and Jiménez-Pérez 2011). For instance, environmental services offer very valuable indirect benefits (Pagiola et al. 2005).

Several studies have demonstrated the best yields obtained by ecosystem services compared to timber uses 
(Martin-Ortega 2013, Álvarez and Rubio 2013). In some cases, environmental services (e.g. carbon sequestration) have an average value 1.47 times higher than that of wood (Álvarez and Rubio 2013). Therefore, knowing the variation of carbon in the different compartments of the tree will help to improve the estimates of the commercial value of the forest for the carbon bonds, and to contribute to the knowledge of carbon flows. Knowing the concentration of carbon in different compartments of the tree provides precise and useful information in generating strategies and actions to counteract climate change, forest productivity and anthropogenic impact (Aguirre-Calderón and Jiménez-Pérez 2011, Wang et al. 2015).

The procedures for estimating carbon content are based on biomass estimation, assuming a $50 \%$ carbon concentration for practical purposes (Lamlom and Savidge 2006). This operational methodology leads to inaccurate results, due to variation of the carbon concentration between arboreal components (Pompa and Yerena 2014) and within tree components (Bert and Danjon 2006, Martin et al. 2015). The stem is the aerial component with the highest biomass and consequently stores significant amounts of carbon, thus knowing longitudinal carbon variation is a priority issue. This specific problem has rarely been studied given the difficulties involved (Castaño-Santamaría and Bravo 2012), although dissimilarities of carbon at different tree heights are well known (Bert and Danjon 2006, Herrero et al. 2011). In Mexico, no study has presented vertical variations of carbon despite the high abundance of Pinaceae (González-Elizondo et al. 2012). The species Pinus durangensis Martínez, P. engelmannii Carrière and P. leiophylla Schiede ex Schltdl. et Cham., have huge ecological and economic interest and they are widely distributed in Nor- thern Mexico (González-Elizondo et al. 2012), therefore they constitute an ideal group of species to contribute to the knowledge of the variations of carbon.

Although recent studies have reduced the uncertainty of carbon calculation around the world (Thomas and Martin 2012, Durkaya et al. 2013), there is a current concern to determine the flow of carbon, which allows having precise indicators for future tradable projects of carbon. The most frequent studies aim at determining the concentrations of carbon in different tree components, finding variations that do not coincide with that of $50 \%$ (Pompa and Yerena 2014). For instance, in Mexican forest many studies use a constant value for carbon concentration (often $50 \%$ ) to model carbon flux in different ecosystems, providing a limited understanding of the role of trees as a carbon sink. Knowing within-tree carbon concentration variation in representative pine species could reduce biases of such estimates. In addition, for this species, to our knowledge, no such effort has been made to date.

By hypothesizing that concentrations of carbon differ from $50 \%$ conventionally assumed, the aim of this study is to assess the variations in carbon concentration along the stem of three species of Pinaceae, including other structures such as root, bark, branches, twigs, leaves and fruits.

\section{METHODS}

Study area. The present study was carried out in the cooperative Sierra del Nayar (2,350 m a.s.l.), which forms part of the municipalities of Durango and Pueblo Nuevo located in the southwest of the state of Durango (northwest of Mexico), within the Occidental Sierra Madre (figure 1). From the study area, a population of three commercial

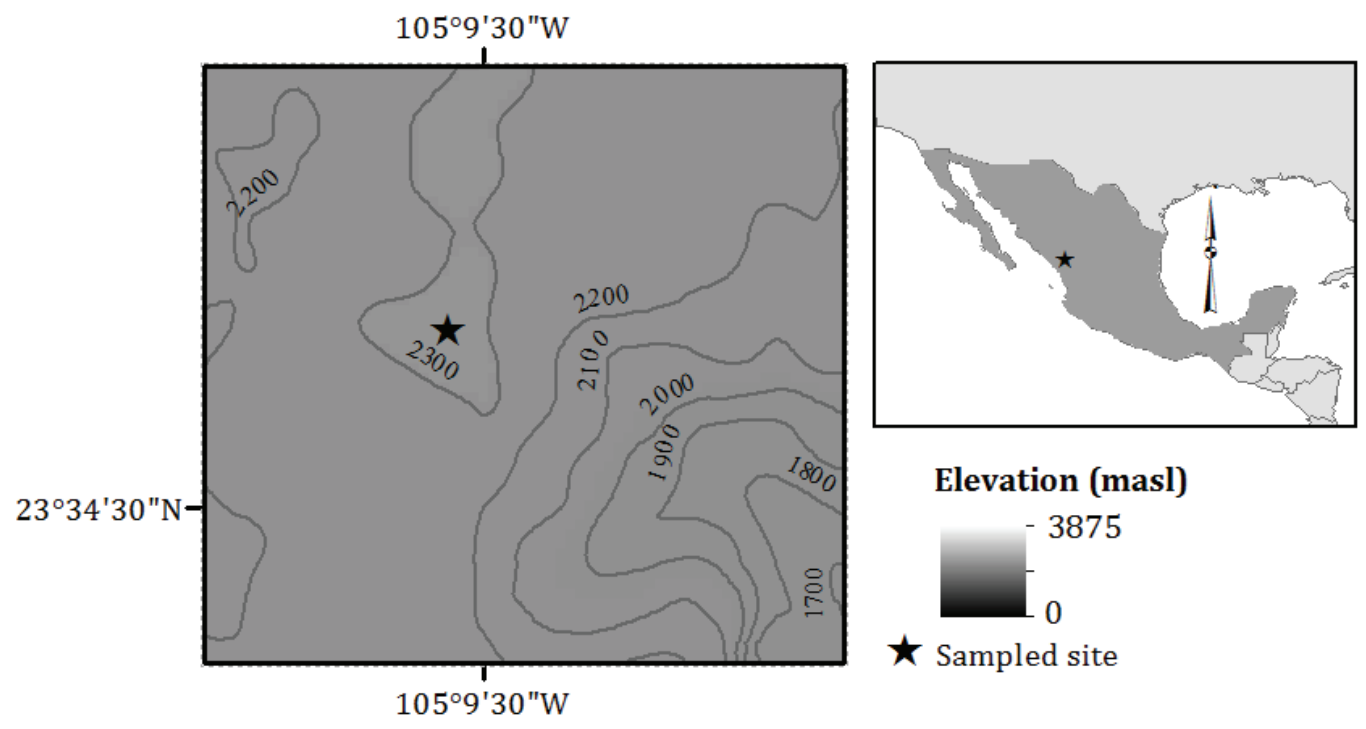

Figure 1. Location of the study area.

Localización del área de estudio. 
pine species was selected: Pinus durangensis, P. engelmannii and P. leiophylla.

The climate of the area is temperate. The dominant vegetation types are Pine and Pine-Oak forests. These mixed forests include $P$. durangensis, $P$. leiophylla, $P$. strobiformis and P. pseudostrobus, which are often associated with Quercus and Arbutus species (González-Elizondo et al. 2012). The forest has an irregular structure, an average site quality, with real stocks per weighted hectare of $78.6 \mathrm{~m}^{3}$ $\mathrm{ha}^{-1}$, density of 520 trees $\mathrm{ha}^{-1}$, and a current annual increment of $1.6 \mathrm{~m}^{3}$ per year (CCMSS 2002).

Data. We used a selective sampling design from the extraction forest stands. A total of well-shaped 12 trees of each species were selected. Trees were of dominant heights and had no signs of damage, had diameters $>35 \mathrm{~cm}$ and were older than 70 years. From each tree, samples of $50 \mathrm{~g}$ of leaves, branches, twigs (diameter $<5 \mathrm{~cm}$ ), bark, root and fruit were collected without any pattern of sampling. Radial cores of each tree were collected using a Pressler increment borer, at different heights: core 1 at $0.30 \mathrm{~m}$, core 2 at $2.74 \mathrm{~m}$, core 3 at $5.18 \mathrm{~m}$, core 4 at $7.62 \mathrm{~m}$ and core 5 at $8.28 \mathrm{~m}$, following the length of commercially sawn timber. The samples were taken to the laboratory following the procedures of Karlik and Chojnacky (2013), and immediately placed in paper bags to minimize the loss of volatile carbon (Lamlom and Savidge 2003, Martin and Thomas 2011). Samples were dried at room temperature until reaching a constant weight. Following the procedure of Lamlon and Savidge (2003), the samples were ground using a pulverizing mill (Fritsch pulverisette 2), which produces fractions smaller than $10 \mu \mathrm{g}$. Total carbon concentration (TCC) was obtained using the Solids TOC Analyzer (1020A from O I Analytical, USA), which analyzes solid samples of $30 \mathrm{mg}$ by complete combustion at a temperature of $900{ }^{\circ} \mathrm{C}$. The resulting gases were measured through a non-dispersive infrared detector that counts the carbon molecules (Yerena et al. 2012).

Statistical analyses. After the verification of the statistical assumptions of normality, homoscedasticity and independence, the data were subjected to an analysis of variance (ANOVA) using the statistical program SAS (Statistical Analysis System 2004) to determine if there were significant differences $(P \geq 0.05)$ in the carbon concentration among the averages of the different heights of the stems, species and their components. We tested two factors (treatments): species, which were divided into three levels (P. engelmannii, P. leiophylla and $P$. durangensis) and components, where seven levels were determined (root, stem, branch, leaves, twig, fruit and bark). Thus, a $3 \times 7$ factorial experimental design with 21 interactions between treatments was analyzed. Whenever significance was observed between factor levels -component groups and species groups-, a totally randomized ANOVA $(P \leq 0.05)$ was performed for the components. Similarly, we performed an
ANOVA to test if there were significant differences along the stem profile of tree species. We determined two factors: species (three levels) and heights (five levels: 0.30, 2.74, 5.18, 7.62 and $8.28 \mathrm{~m})$, with 15 interactions $(3 \times 5)$. When significance was found, we used a totally randomized ANOVA design for stem heights. When statistical differences were detected, we compared the means with a Tukey test $(P=0.05)$.

\section{RESULTS}

There was more carbon in the two lowest heights of the stems $(P=0.002$, table 1$)$. Pinus engelmannii with $49.31 \%$ had the lowest carbon concentration, while P. leiophylla and P. durangensis (50.18\% and $50.36 \%$, respectively) had higher concentrations ( $P=0.005$, table 2$)$.

There were differences among the components across species $(P<0.0001)$. Across species, carbon concentration was higher for bark (52.48 \%) than for other components, and was similar for the groups formed by rootstem-branch-leaves and stem-branch-leaves-twigs-fruits (table 3).

The range of variation of carbon concentration among the components of the species was 6.1 percentage points, from $47.39 \%$ in the P. engelmannii root to $53.49 \%$ in the bark of $P$. leiophylla $(P=0.006)$. The Tukey test

Table 1. Carbon concentration of different heights along the stem. fil longitudinal.

Concentraciones de carbono de las diferentes alturas en el per-

\begin{tabular}{ccc}
\hline $\begin{array}{c}\text { Tree cores at different } \\
\text { heights }(\mathrm{m})\end{array}$ & Mean \pm SE & $\begin{array}{c}\text { Tukey }^{1} \\
\text { grouping }\end{array}$ \\
\hline $1-0.30$ & $49.08 \pm 0.40$ & $\mathrm{~A}$ \\
$2-2.74$ & $49.14 \pm 0.36$ & $\mathrm{~A}$ \\
$3-5.18$ & $48.14 \pm 0.34$ & $\mathrm{~B}$ \\
$4-7.62$ & $47.40 \pm 0.42$ & $\mathrm{~B}$ \\
$5-8.28$ & $47.86 \pm 0.32$ & $\mathrm{~B}$ \\
\hline
\end{tabular}

${ }^{1}$ Means with different letters are statistically different (Tukey $P=0.05$ ).

Table 2. Carbon concentration of species (\%).

Concentración de carbono de las especies (\%).

\begin{tabular}{lc}
\hline \multicolumn{1}{c}{ Species } & Mean \pm SE \\
\hline Pinus engelmannii & $49.31 \pm 0.22 \mathrm{a}$ \\
Pinus leiophylla & $50.18 \pm 0.27 \mathrm{~b}$ \\
Pinus durangensis & $50.36 \pm 0.18 \mathrm{~b}$ \\
\hline
\end{tabular}

Means with different letters are statistically different (Tukey $P=0.05$ ). $\mathrm{EE}=$ standard error of the sample. 
$(P=0.05)$ showed six groups of means. The roots and stems of the three species together with branches of $P$. leiophylla and $P$. engelmannii, leaves of $P$. engelmannii and $P$.durangensis had lowervalues (from 47.39 to $49.57 \%$ ); in contrast, bark of the species had the highest carbon concentration of all components of the species, with values ranging from 51.47 to $53.49 \%$ (table 4 ).

\section{DISCUSSION}

This is the first study that shows differences in the concentration of carbon along heights of the stems and tissues in Mexican pine species. This study has evidenced that even in the same stem there are variations that should be considered to improve the estimates of the assimilation capacity of carbon in the forest. As with Bert and Danjon (2006), the results showed differences in the concentration of carbon that were found in each sample obtained from the longitu-

Table 3. Carbon concentration per component of all species (\%). cies $(\%)$.

Concentración de carbono por componente de todas las espe-

\begin{tabular}{lc}
\hline \multicolumn{1}{c}{ Component } & Mean \pm SE \\
\hline Root & $48.72 \pm 0.31 \mathrm{a}$ \\
Stem & $49.23 \pm 0.36 \mathrm{ab}$ \\
Branch & $49.32 \pm 0.41 \mathrm{ab}$ \\
Leaves & $49.59 \pm 0.15 \mathrm{ab}$ \\
Twig & $50.24 \pm 0.15 \mathrm{~b}$ \\
Fruit & $50.47 \pm 0.29 \mathrm{~b}$ \\
Bark & $52.48 \pm 0.17 \mathrm{c}$ \\
\hline
\end{tabular}

Means with different letters are statistically different (Tukey $P=0.05$ ). $\mathrm{SE}=$ standard error of the sample. dinal cut of the stem and the maximum value was always found at the base of the tree. A possible explanation for these values found is attributed to the geometric effect and age at the base. This is explained by the fact that, at an older age, rings with a higher percentage of latewood are formed and this increases the density of the wood (Bert and Danjon 2006). It is also well known that, comparatively, late wood has more carbon than that found in early wood (Pallardy 2008). In contrast, the amount of early wood increases as the height of the tree grows. Consequently, the chemical composition of the base gradually differentiates along the vertical profile. This implies that, if the concentration of carbon along the stem varies, sampling should be carried out by weighting this aspect. Recent studies have shown that variations in biomass and hence carbon, depend on the height of the stem (Jones and O'Hara 2012). Although this analysis goes beyond the objectives of the present study, a representative stem height should be considered. Until now, considering $1.3 \mathrm{~m}$ as a source of information could produce biased values, despite the advantage of non-destructive methods (e.g., tree core extraction using Pressler borer).

Our results showed significant differences in mean carbon concentration among species, with two groups of differentiated means: on the one hand, P. engelmannii that is a species of wide ecological distribution, varying from 1,800 to 2,600 m a.s.l. (González-Elizondo et al. 2012), therefore their low concentrations of carbon could be attributed to the minimum nutrition requirements. The other group consists of $P$. leiophylla and $P$. durangensis, with higher values. According to Sáenz-Esqueda et al. (2010) these species are rich in volatiles and carbohydrates that contribute to increase the concentrations of carbon.

Significant differences of carbon concentration among components were evident (see table 4). The high concentration value of carbon in the bark agrees with Zhang et al. (2014), who found that bark contains high concentrations of carbon. Similarly, in the study by Bert and Danjon

Table 4. Average concentration of carbon per component per species.

Concentración promedio de carbono por componente por especies.

\begin{tabular}{lcllll}
\hline \multicolumn{2}{c}{ Pinus engelmannii } & \multicolumn{2}{c}{ Pinus leiophylla } & \multicolumn{2}{c}{ Pinus durangensis } \\
\hline \multicolumn{1}{c}{ Component } & Mean $\pm \mathrm{SE}$ & \multicolumn{1}{c}{ Component } & Mean $\pm \mathrm{SE}$ & Component & Mean $\pm \mathrm{SE}$ \\
\hline Root & $47.39 \pm 0.65 \mathrm{a}$ & Branch & $48.34 \pm 1.14 \mathrm{ab}$ & Root & $49.19 \pm 0.33 \mathrm{abcd}$ \\
Leaves & $48.71 \pm 0.13 \mathrm{abc}$ & Stem & $49.06 \pm 0.51 \mathrm{abc}$ & Leaves & $49.44 \pm 0.19 \mathrm{abcd}$ \\
Stem & $49.08 \pm 0.75 \mathrm{abc}$ & Root & $49.57 \pm 0.35 \mathrm{abcd}$ & Stem & $49.54 \pm 0.67 \mathrm{abcd}$ \\
Branch & $49.15 \pm 0.25 \mathrm{abc}$ & Fruit & $49.91 \pm 0.17 \mathrm{bcd}$ & Branch & $50.48 \pm 0.29 \mathrm{bcde}$ \\
Twig & $49.83 \pm 0.23 \mathrm{bcd}$ & Twig & $50.05 \pm 0.18 \mathrm{bcd}$ & Fruit & $50.72 \pm 0.52 \mathrm{bcde}$ \\
Fruit & $50.57 \pm 0.08 \mathrm{bcde}$ & Leaves & $50.61 \pm 0.11 \mathrm{bcde}$ & Twig & $50.82 \pm 0.29 \mathrm{cde}$ \\
Bark & $51.47 \pm 0.14 \mathrm{def}$ & Bark & $53.49 \pm 0.23 \mathrm{f}$ & Bark & $52.49 \pm 0.18 \mathrm{ef}$ \\
\hline
\end{tabular}

Means with different letters are statistically different (Tukey $P=0.05$ ).

$\mathrm{SE}=$ standard error of the sample. 
(2006), bark was the part of the tree with the highest concentration of carbon. In contrast, roots and stems had low values of carbon across species, which has been attributed to the chemical composition of cellulose and lignin, the primary components of wood (Fonseca et al. 2012).

Usually the most conventional method to determine the amount of stored carbon is by multiplying the total dry weight of trees by a coefficient of 0.5 (Durkaya et al. 2013). In the case of the average concentration of carbon in the components of the three species, the variation was between $47 \%$ and $53 \%$. This result is consistent with those found by other authors (Thomas and Martin 2012, Durkaya et al. 2013, Pompa and Yerena 2014) and would be helpful to improve carbon estimations in Mexican forests (Carrillo et al. 2016).

\section{CONCLUSIONS}

Carbon concentration for three Mexican pines differed among species, stem height and tissues. Results for this study show that the generalized $50 \%$ of carbon concentration assumption may produce consistently misleading estimates. Therefore, variations in compartments should at least be considered when attempting to define the most appropriate carbon fraction used to estimate carbon stocks in Mexican pine species. These multi-species data contribute to improve precision on estimates of carbon balance in terrestrial ecosystems, to yield superior insights into the carbon inventories. Additional comparative analyses of inter- and intraspecific variations are needed to reduce uncertainty of carbon variation in forest ecosystem.

\section{ACKNOWLEDGEMENTS}

We recognize financial support from CONACyT (CB2013/222522) in Mexico. Also, we thank the editor for an early review of this manuscript and two anonymous reviewers that helped to improve the article.

\section{REFERENCES}

Aguirre-Calderón OA, J Jiménez-Pérez. 2011. Evaluación del contenido de carbono en bosques del sur de Nuevo León. Revista Mexicana de Ciencias Forestales 2(6): 73-84.

Álvarez S, A Rubio. 2013. Carbon baseline in a mixed pine-oak forest in the Juarez mountain range (Oaxaca, Mexico) using the co2fix v.3.2 model. Revista Chapingo Serie Ciencias Forestales y del Ambiente 19(1): 125-137.

Bert D, F Danjon. 2006. Carbon concentration variations in the roots, stem and crown of mature Pinus pinaster (Ait.). Forest Ecology and Management 222: 279-295.

Carrillo AF, MA Mireles, CDRJ Cruz, LG Molina, JDE Barra. 2016. Ecuaciones alométricas para estimar la biomasa y el carbono de la parte aérea de Pinus hartwegii en el Parque Nacional Ixta-Popo, México. Revista Mexicana de Ciencias Agrícolas 7(3): 681-691.

Castaño-Santamaría J, F Bravo. 2012. Variation in carbon con- centration and basic density along stems of sessile oak (Quercus petraea (Matt.) Liebl. and Pyrenean oak (Quercus pyrenaica Willd.) in the Cantabrian Range (NM Spain). Annals of Forest Science 69(6): 663-672.

CCMSS (Consejo Civil Mexicano para la Silvicultura Sostenible, MX). 2002. Resumen Público de Certificación de Sociedad Civil "Sierra del Nayar". México DF, México. 35 p. Consultado 02 ene. 2016. Disponible en http://www.rainforest-alliance.org/business/forestry/documents/nayar.pdf

Durkaya B, A Durkaya, E Makineci, M Ülküdür. 2013. Estimation of above-ground biomass and sequestered carbon of Taurus Cedar (Cedrus libani L.) in Antalya, Turkey. iForest 6(5): 278-284.

Fonseca W, FE Alice, JM Rey-Benayas. 2012. Carbon accumulation in aboveground and belowground biomass and soil of different age native forest plantations in the humid tropical lowlands of Costa Rica. New Forest 43(2): 197-211.

González-Elizondo MS, M González-Elizondo, JA Tena-Flores, L Ruacho-González, IL López-Enríquez. 2012. Vegetación de la Sierra Madre Occidental, México: Una síntesis. Acta Botánica Mexicana 100: 351-403.

Herrero C, MB Turrión, V Pando, F Bravo. 2011. Carbon in heartwood, sapwood and bark along the stem profile in three Mediterranean Pinus species. Annals of Forest Science 68(6):1067-1076.

Jones DA, KL O'Hara. 2012. Carbon density in managed coast redwood stands: implications for forest carbon estimation. Forestry 85(1): 99-110.

Karlik FJ, CD Chojnacky. 2013. Biomass and carbon data from blue oaks in a California oak savanna. Biomass and Bioenergy 62: 228-232.

Lamlom SH, RA Savidge. 2003. A reassessment of carbon content in wood: variation within and between 41 North American species. Biomass and Bioenergy 25(4): 381-388.

Lamlom SH, RA Savidge. 2006. Carbon content variation in boles of mature sugar maple and giant sequoia. Tree Physio$\operatorname{logy} 26(4)$ : 459-468.

Martin AR, SC Thomas. 2011. A reassessment of carbon content in tropical trees. PLoS One 6(8): e23533.

Martin AR, S Gezahegn, SC Thomas. 2015. Variation in carbon and nitrogen concentration among major woody tissue types in temperate trees. Canadian Journal of Forest Research 45:744-757.

Martin-Ortega J, E Ojea, C Roux. 2013. Payments for Water Ecosystem Services in Latin America: A literature review and conceptual model. Ecosystem Services 6: 122-132.

OMM (Organización Meteorológica Mundial, CH). 2016. Declaración de la OMM sobre el estado del clima mundial en 2015. Ginebra, Suiza. OMM. 25 p.

Pagiola S, A Arcenas, G Platais. 2005. Can payments for environmental services help reduce poverty? An exploration of the issues and the evidence to date from Latin America. World Development 33(2): 237-253.

Pallardy SG. 2008. Physiology of woody plants. San Diego, USA. Academic Press. 454 p.

Pompa M, JI Yerena. 2014. Concentration of carbon in Pinus cembroides Zucc: Mitigation potential source of global warming. Revista Chapingo Serie Ciencias Forestales y del Ambiente 20(3): 169-175.

Sáenz-Esqueda MA, M Rosales-Castro, NE Rocha-Guzmán, JA Gallegos-Infante, RF González-Laredo. 2010. Contenido 
fenólico y acción antioxidante de extractos de acículas de Pinus cooperi, $P$. durangensis, $P$. engelmanii y $P$. teocote. Madera y Bosques 16(3): 37-48.

SAS (Statistical Analysis System, US). 2004. SAS user's guide statistics. Release 9.1. Cary, NC, USA. SAS Institute Inc.

Thomas S, A Martin. 2012. Carbon Content of Tree Tissues: A Synthesis. Forest 3(2): 332-352.

Wang XW, YH Weng, GF Liu, MJ Krasowski, CP Yang. 2015. Variations in carbon concentration, sequestration and par- titioning among Betula platyphylla provenances. Forest Ecology and Management 358: 344-352.

Yerena JI, J Jiménez, OA Aguirre, EJ Treviño. 2012. Contenido de carbono total de especies arbóreas y arbustivas en áreas con diferente uso, en el matorral espinoso tamaulipeco, en México. Bosque 33(2): 145-152.

Zhang H, C Wang, X Wang. 2014. Spatial variations in nonstructural carbohydrates in stems of twelve temperate tree species. Trees - Structure and Function 28(1): 77-89.

Recibido: 21.03 .17

Aceptado: 15.05.17 